\title{
STUDI PENGARUH SUHU AIR TERHADAP AKTIVITAS BAKTERI BIOREMEDIASI (NITROSOMONAS DAN NITROBACTER) PADA PEMELIHARAAN BENIH IKAN PATIN SIAM (Pangasius hypopthalmus)
}

\author{
Imam Taufik*), Sutrisno*), Parwatining Yuliati*), Hambali Supriyadi*), \\ Siti Subandiyah"), dan Irvan Muthalib")
}

\begin{abstract}
ABSTRAK
Studi pengaruh suhu dalam aktivitas bakteri bioremediasi telah diamati dalam rangka menanggulangi penurunan kualitas air pada budi daya ikan patin siam, sehingga mampu meningkatkan sintasan dan memacu pertumbuhan. Wadah yang digunakan berupa 15 akuarium kaca $\left(70 \times 40 \times 45 \mathrm{~cm}^{3}\right)$ dilengkapi dengan aerasi. Benih ikan patin ukuran 0,2 g/ekor yang digunakan sebagai hewan uji diberi pakan buatan dengan kandungan protein $40 \%$ sekenyangnya, dan frekuensi pemberian 3 kali. Rancangan percobaan menggunakan Rancangan Acak Lengkap (RAL) dengan 3 ulangan dan benih dipelihara selama 56 hari. Kepadatan bakteri bioremediasi $10^{4} \mathrm{cfu} / \mathrm{mL}$ dengan perlakuan suhu, yaitu: A) $31^{\circ} \mathrm{C} \pm 0,5^{\circ} \mathrm{C}$; B) $29^{\circ} \mathrm{C} \pm 0,5^{\circ} \mathrm{C}$; C) $28^{\circ} \mathrm{C} \pm 0,5^{\circ} \mathrm{C}$; D) suhu ruang; dan E) suhu ruang tanpa bakteri. Hasil penelitian menunjukkan bahwa suhu air tidak berpengaruh terhadap perkembangan bakteri bioremediasi tetapi berpengaruh terhadap sintasan dan pertumbuhan serta sifat fisika-kimia air.
\end{abstract}

\begin{abstract}
The effect of water temperature on the development of bioremediation bacteria on Pangasius hypopthalmus larval rearing. By: Imam Taufik, Sutrisno, Parwatining Yuliati, Hambali Supriyadi, Siti Subandiyah, and Irvan Muthalib

The aims of this study were to obtain the optimum temperature on bioremediation bacteria activity in Pangasius hypopthalmus larval rearing. Fifteen aquariums were used and provided with aeration, Pangasius fry was feed pellet with protein contains of $40 \%$ at satiation for 3 times/ day. This study was conducted as long as 56 days. CRD (Complete Randomized Design) was used in this analyses. The density of bioremediation bacteria was $10^{4} \mathrm{cfu} / \mathrm{mL}$, and temperature treatments were A) $31^{\circ} \mathrm{C} \pm 0.5^{\circ} \mathrm{C}$; B) $29^{\circ} \mathrm{C} \pm 0.5^{\circ} \mathrm{C}$; C) $28^{\circ} \mathrm{C} \pm 0.52^{\circ} \mathrm{C}$; D) room temperature; and E) control (without bacteria). The result showed that water temperature gave no significant different of bacteria growth but survival and growth rate of pangasius were showed significantly different $(P<0.05)$.
\end{abstract}

KEYWORDS: bioremediation, growth, pangasius, survival rate, temperature

\section{PENDAHULUAN}

Kenyataan yang tidak dapat dihindari dari kegiatan budi daya ikan adalah terdegradasinya lingkungan pemeliharaan akibat limbah dari kegiatan budi daya tersebut, karena dalam kegiatan budi daya memiliki dua hal yang saling berlawanan, yaitu: 1) membutuhkan lingkungan yang cocok atau bersih, dan 2) kegiatan ini menghasilkan limbah yang berdampak negatif.

Degradasi lingkungan akibat limbah budi daya dapat bersumber dari pasokan pakan, karena pakan yang dimanfaatkan untuk membentuk daging ikan sebenarnya hanya $20 \%-30 \%$ dari jumlah yang diberikan (Thang, 1997). Sisa pakan yang tidak dikonsumsi dan tidak dicerna (feces) akan mengalami pembusukan atau perombakan oleh bakteri pengurai. Produk utama dari perombakan bahan organik tersebut adalah amonia $\left(\mathrm{NH}_{3}\right)$ yang pada konsentrasi tertentu akan bersifat toksik terhadap ikan. Selain itu, terakumulasinya materi organik ini dapat menimbulkan kondisi lingkungan perairan yang cocok untuk berkembang biaknya berbagai mikroorganisme yang dapat menjadi sumber penyakit (Powell, 1986).

Dalam usaha pendederan ikan patin secara komersial, pada umumnya dilakukan dalam lingkungan perairan yang sangat terbatas dengan padat penebaran tinggi dan pemberian pakan secara berlebih (ad libitum). Hal ini dilakukan untuk mencapai target produksi guna memperoleh keuntungan yang maksimal. Dampak dari upaya tersebut akan menghasilkan limbah bahan organik dalam jumlah 
banyak yang akan mengalami pembusukan dan menghasilkan amonia yang bersifat racun sehingga sangat potensial sebagai sumber pencemaran air.

Secara teknis upaya perbaikan kualitas media air dilakukan dengan penyiponan dan atau penggantian air secara berkala (Susanto, 1987). Cara ini ternyata masih menimbulkan resiko kematian ikan yang cukup tinggi yang disebabkan karena stres, disamping diperlukan waktu yang lama serta tenaga dan biaya yang cukup besar.

Alternatif untuk mempertahankan kualitas lingkungan perairan secara efektif dan efisien adalah dengan menerapkan metode bioremediasi, karena menurut Stickney (1979) bakteri dapat berperan sebagai filter biologis, karena dapat mengkonversi amonia menjadi nitrit melalui bentuk intermediet dan selanjutnya dipakai oleh bakteri untuk proses dekomposisi dan diubah menjadi nitrat.

Dalam aplikasinya, konsep bioremediasi harus disesuaikan dengan kondisi lingkungan karena bakter yang digunakan akan menjadi bagian dari lingkungan itu sendiri. Sehubungan dengan hal tersebut perlu dilakukan penelitian untuk mengetahui suhu yang optimal dalam penggunaan bakteri bioremediasi untuk menanggulangi pencemaran air akibat limbah budi daya dalam pendederan ikan patin.

\section{BAHAN DAN METODE}

Percobaan dilaksanakan di Instalasi Riset Lingkungan Perikanan Budidaya dan Toksikologi, Cibalagung. Rancangan yang digunakan adalah Rancangan Acak Lengkap (RAL) dengan tiga ulangan, dilakukan dalam ruang tertutup dengan wadah berupa 15 akuarium kaca ukuran $70 \times 40 \times 45 \mathrm{~cm}^{3}(p \times \mid \times t)$ yang dilengkapi dengan aerasi

Wadah penelitian diisi air tawar sebanyak 50 liter dan dirancang menggunakan sistem resirkulasi yang dilengkapi bak filter dengan materi berupa dakron dan batu koral. Air di dalam bak filter sebanyak 100 liter, sehingga total volume air dalam setiap unit penelitian adalah 150 liter.

Hewan uji yang digunakan adalah benih ikan patin siam (Pangasius hypopthalmus) dengan ukuran bobot rata-rata 0,2 g/ekor yang diperoleh dari hasil pemijahan secara terkontrol dan ditebar sebanyak 250 ekor/wadah. Selama penelitian ikan diberi pakan komersil dengan kandungan protein $40 \%$ secara at satiation (sekenyangnya) dengan frekuensi pemberian 3 kali/hari.

Untuk menjaga kestabilan suhu air selama penelitian digunakan pemanas yang ditempatkan dalam setiap wadah penelitian. Perlakuan yang diterapkan berupa perbedaan suhu air pemeliharaan sebagai berikut:
A. Suhu $31^{\circ} \mathrm{C} \pm 0,4^{\circ} \mathrm{C}$ dengan inokulasi bakteri bioremediasi

B. Suhu $29^{\circ} \mathrm{C} \pm 0,4^{\circ} \mathrm{C}$ dengan inokulasi bakteri bioremediasi

C. Suhu $28^{\circ} \mathrm{C} \pm 0,4^{\circ} \mathrm{C}$ dengan inokulasi bakteri bioremediasi

D. Suhu ruang $\left(24^{\circ} \mathrm{C}-27^{\circ} \mathrm{C}\right)$ dengan inokulasi bakteri bioremediasi

E. Kontrol, suhu ruang $\left(24^{\circ} \mathrm{C}-27^{\circ} \mathrm{C}\right)$ tanpa inokulasi bakteri bioremediasi

Bakteri bioremediasi yang dipakai adalah bakteri Nitrosomonas dan Nitrobacter yang merupakan koleksi Instalasi Riset Kesehatan Ikan, Pasar Minggu. Bakteri dibiakkan terlebih dahulu di dalam media Tryptic Soy Broth (TSB) yang diperkaya dengan glukosa $1 \%$ dan diinkubasi selama 12 jam, kemudian diinokulasikan dalam sistem resirkulasi dengan cara menyebarkan inokulan bakteri tersebut secara merata ke dalam air

Bakteri Nitrosomonas sebanyak $10^{4} \mathrm{cfu} / \mathrm{mL}$ diinokulasikan terlebih dahulu dengan cara membiarkan air mengalir dan berputar pada sistem resirkulasi selama 3 hari. Selama pengkondisian bakteri, ikan uji tidak ditempatkan dalam wadah penelitian. Selanjutnya inokulasi bakteri Nitrobacter sebanyak $10^{4} \mathrm{cfu} / \mathrm{mL}$ dilakukan pada hari ke-7 pemeliharaan ikan uji ketika kadar nitrit dalam air mulai meningkat. Penghitungan jumlah bakteri menggunakan metode pengenceran seri yang kemudian ditanamkan di atas media Tryptic Soy Agar (TSA) pada petri dish.

Pemantauan perkembangan bakteri bioremediasi dalam air dilakukan setiap hari hingga populasi bakteri mencapai puncak kepadatan. Hasil perhitungan bakteri merupakan koreksi dari jumlah bakteri dalam tiap perlakuan dikurangi jumlah bakteri pada kontrol (bakteri alami dalam air)

Waktu penelitian selama 8 minggu (56 hari) dengan sampling penimbangan bobot ikan dilakukan setiap minggu. Parameter yang diamati meliputi perkembangan bakteri dalam air, sintasan (survival rate), laju pertumbuhan, konversi pakan, dan sifat fisika-kimia air.

Sintasan dihitung dengan membandingkan jumlah hewan uji yang hidup pada akhir pengamatan terhadap jumlah hewan uji pada awal pengamatan dan dinyatakan dalam bentuk persentase:

$$
S R=N t / \text { No } \times 100 \%
$$

di mana:

$S R=$ survival rate $(\%)$

No $=$ jumlah hewan uji pada awai penelitian (ekor) $N t=$ jumlah hewan uji pada akhir penelitian (ekor) 
Laju pertumbuhan harian (spesific growth rate) diukur dengan menggunakan rumus Steffen (1989), yaitu:

$$
S G R=\ln W_{t}-\ln W_{0} / t_{1}-t_{0} \times 100 \%
$$

di mana:

$S G R=$ laju pertumbuhan harian $(\%)$

$W_{0}=$ bobot ikan uji pada awal penelitian (g)

$W_{t}=$ bobot ikan uji pada akhir penelitian $(\mathrm{g})$

$t_{0}=$ waktu awal penelitian (hari)

$t_{1}=$ waktu akhir penelitian (hari)

Seminggu sekali dilakukan pengukuran beberapa sifat fisika-kimia air, yaitu: suhu air, $\mathrm{pH}, \mathrm{O}_{2}, \mathrm{CO}_{2}$, amonia, nitrit, nitrat, kesadahan, alkalinitas, dan bahan organik.

Data pertumbuhan, sintasan, dan konversi pakan dianalisis varian untuk mengetahui masing-masing perlakuan terhadap setiap parameter yang diukur, sedangkan perkembangan bakteri dan sifat fisikakimia air dianalisis secara deskriptif.

\section{HASIL DAN BAHASAN}

\section{Kepadatan Bakteri}

Bakteri bioremediasi adalah bakteri yang bekerja melalui proses nitrifikasi dengan memanfaatkan aktivitas bakteri Nitrosomonas dan Nitrobacter. Kedua jenis bakteri tersebut bekerja secara simultan, bakteri Nitrosomonas merombak amonia menjadi nitrit, kemudian oleh bakteri Nitrobacter produk nitrit tersebut diubah menjadi nitrat sehingga lingkungan perairan menjadi stabil.
Jumlah bakteri Nitrosomonas dan Nitrobacter yang ditambahkan ke dalam air pemeliharaan benih patin pada setiap unit penelitian, masing-masing sebanyak $1,2 \times 10^{4} \mathrm{cfu} / \mathrm{mL}$. Jumlah tersebut dari hasil uji pendahuluan terbukti merupakan kepadatan bakteri bioremediasi yang paling efektif untuk mengkonversi amoniak menjadi nitrat melalui bentuk intermediet sehingga tidak membahayakan bagi ikan uji

Dari hasil penghitungan jumlah bakteri yang dilakukan setiap 24 jam selama 12 hari, terlihat bahwa pertumbuhan bakteri Nitrosomonas pada suhu air yang berbeda cukup pesat, dalam waktu 24 jam kepadatannya telah mencapai $10^{9} \mathrm{cfu} / \mathrm{mL}$ untuk perlakuan $A, C$, dan $D$ bahkan pada perlakuan $B$ mencapai $10^{10} \mathrm{cfu} / \mathrm{mL}$ meski pada hari ke-2 turun kembali menjadi $10^{9} \mathrm{cfu} / \mathrm{mL}$. Pada perlakuan E (kontrol), bakteri alami yang terdapat dalam air juga berkembang dari kepadatan $10^{2} \mathrm{cfu} / \mathrm{mL}$ menjadi $10^{3}$ $\mathrm{cfu} / \mathrm{mL}$ dalam periode yang sama. Selanjutnya, jumlah bakteri pada setiap perlakuan relatif konstan dan bertahan pada kepadatan masing-masing sampai hari ke-12, periode seperti ini menurut Pelczar \& Chan (1986) merupakan fase statis di mana tidak ada pertambahan populasi bakteri (Gambar 1).

Seperti halnya Nitrosomonas, bakteri Nitrobacter yang diinokulasikan dalam air juga mengalami pertumbuhan untuk semua perlakuan (kecuali kontrol). Dalam waktu 24 jam kepadatan Nitrobacter mencapai $10^{8} \mathrm{cfu} / \mathrm{mL}$ dan tumbuh menjadi $10^{9} \mathrm{cfu} / \mathrm{mL}$ setelah 48 jam, kemudian memasuki fase statis (log) sampai hari ke-5. Selanjutnya menurun secara perlahan (fase kematian) hingga kepadatan $10^{6}-10^{7} \mathrm{cfu} / \mathrm{mL}$ pada

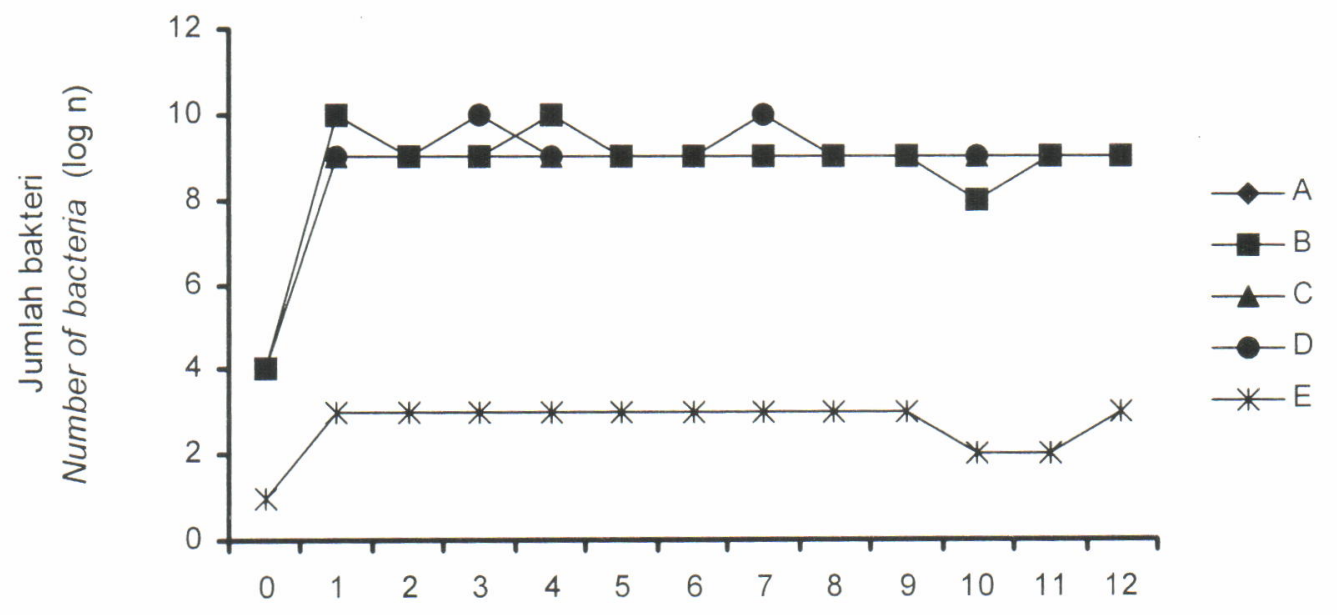

Waktu pengamatan (hari)

Time (Days)

Gambar 1. Perkembangan bakteri Nitrosomonas (cfu/mL) dalam air pada berbagai suhu perlakuan Figure 1. Growth of Nitrosomonas bacteria $(\mathrm{cfu} / \mathrm{mL})$ on the different water temperatures treatment 
hari ke-9 sampai hari ke-12. Pada kontrol, pertumbuhan bakteri langsung memasuki fase statis pada kepadatan $10^{3} \mathrm{cfu} / \mathrm{mL}$ selama 7 hari, dan mengalami penurunan hingga $10^{2} \mathrm{cfu} / \mathrm{mL}$ pada hari ke-12.

Dari hasil perhitungan jumlah bakteri, ternyata perbedaan suhu air antara $25^{\circ} \mathrm{C}-31^{\circ} \mathrm{C}$ tidak berpengaruh nyata terhadap perkembangan jumlah bakteri bioremediasi (Nitrosomonas dan Nitrobacter) (Gambar 2). Hal ini menurut Salle (1961), disebabkan karena bakteri nitrifikasi mempunyai daya toleransi suhu yang cukup lebar untuk dapat berkembang biak, yakni antara $10^{\circ} \mathrm{C}-37^{\circ} \mathrm{C}$. Namun suhu optimal yang dikehendaki bakteri agar dapat beraktivitas dan berkembang biak dengan baik berada pada kisaran suhu $25^{\circ} \mathrm{C}-29^{\circ} \mathrm{C}$

Selain ditunjang oleh suhu air yang optimal, perkembangan bakteri Nitrosomonas juga didukung oleh keberadaan amonia dalam air yaitu sebesar 0,076 $\mathrm{mg} / \mathrm{L}$ yang berasal dari sisa pakan dan metabolisme ikan. Menurut Salle (1961), bakteri Nitrosomonas memperoleh energi dari proses pengubahan amonia menjadi nitrit, dan bakteri ini akan tumbuh baik jika pada media hidupnya terdapat komponen amonia. Dari hasil pengukuran terbukti bahwa amonia dalam air menurun setelah memasuki hari ke- 8 pada perlakuan $A, B, D$, dan $C$, yaitu secara berturut-turut menjadi $0,011-0,016 \mathrm{mg} / \mathrm{L} ; 0,011-0,019 \mathrm{mg} / \mathrm{L} ; 0,016-0,018$ $\mathrm{mg} / \mathrm{L}$; dan 0,016-0,019 mg/L. Pada perlakuan E (kontrol) juga terjadi penurunan amonia walaupun lebih rendah (menjadi 0,021-0,024 mg/L), hal ini menurut Poernomo \& Bittner (1989), dapat disebabkan oleh aktivitas bakteri Nitrosomonas karena bakteri tersebut secara alami terdapat dalam air.

Penurunan konsentrasi amonia dalam air akibat aktivitas bakteri Nitrosomonas diimbangi oleh peningkatan konsentrasi nitrit yang merupakan bentuk peralihan dari amonia. Awal konsentrasi nitrit dalam air sebesar 0,091 mg/L untuk semua perlakuan mulai mengalami peningkatan setelah memasuki hari ke-8 dan pada perlakuan $B$ mencapai puncaknya pada hari ke-22 sebesar 0,318-2,482 mg/L. Sedangkan pada perlakuan $A, D, C$, dan E peningkatan nitrit terbesar terjadi pada hari ke-26, yaitu secara berurut sebesar $0,221-0,753 \mathrm{mg} / \mathrm{L} ; 0,376-5,790 \mathrm{mg} / \mathrm{L} ; 0,608-$ $7,690 \mathrm{mg} / \mathrm{L} ;$ dan $0,219-1,579 \mathrm{mg} / \mathrm{L}$.

Setelah nitrit terbentuk dan terakumulasi maka Nitrobacter akan tumbuh dengan mengkonsumsi nitrit tersebut dan kemudian menguraikannya menjadi nitrat (Purwakusuma, 2003). Dengan demikian ion nitrat terbentuk oleh oksidasi lengkap dari ion amonium oleh mikroorganisme yang ada di tanah atau air (EPA, 1986) atau akibat proses nitrifikasi dari amonia (Cole, 1988).

Mekanisme pembentukan dan penguraian amonia dalam perairan melalui proses nitrifikasi terjadi dalam dua tahap, yaitu

1. $\mathrm{NH}_{4}^{+}+1 \frac{1}{2} \mathrm{O}_{2} \longrightarrow \mathrm{NO}_{2}+2 \mathrm{H}^{+}+\mathrm{H}_{2} \mathrm{O}$, dan

2. $\mathrm{NO}_{2}+1 / 2 \mathrm{O}_{2} \longrightarrow \mathrm{NO}_{3}$.

Oksidasi amonia tersebut dilakukan oleh bakteribakteri kemoautotrof, yaitu bakteri Nitrosomonas pada tahap pertama dan bakteri Nitrobacter pada tahap kedua. Pada proses nitrifikasi ini bakteri menggunakan

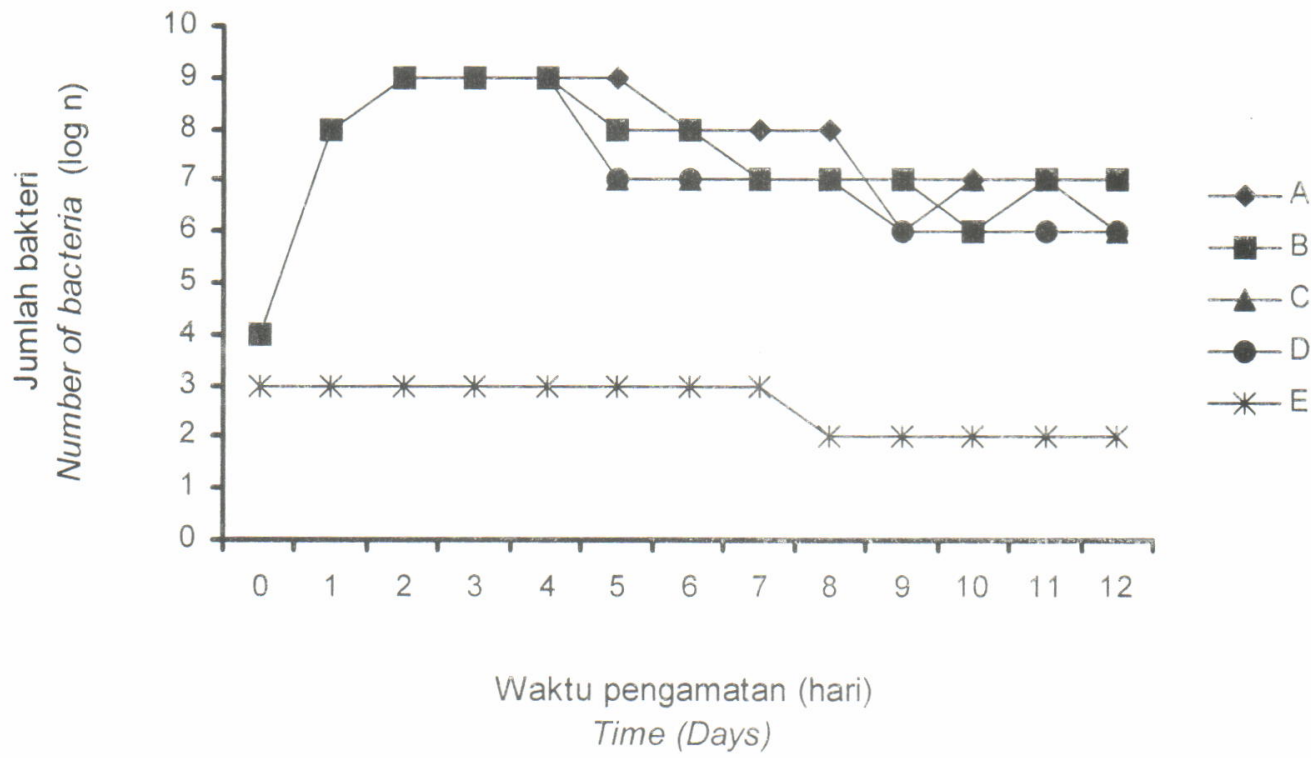

Gambar 2. Perkembangan bakteri Nitrobacter (cfu/mL) dalam air pada berbagai suhu perlakuan Figure 2. Growth of Nitrobacter bacteria $(\mathrm{cfu} / \mathrm{mL})$ on the different water temperatures treatment 
amonium dan nitrit sebagai sumber energi dan karbondioksida dalam air sebagai sumber karbon.

Terurainya nitrit akibat aktivitas bakteri Nitrobacter akan meningkatkan konsentrasi nitrat dalam air. Peningkatan konsentrasi nitrat yang cukup besar terjadi setelah hari ke-15 pada perlakuan $A, B, C, D$, dan $E$ dengan penambahan konsentrasi secara berurutan berkisar antara: 0,048-0,109; 0,0610,$127 ; 0,044-0,100 ; 0,066-0,071 ;$ dan $0,026-0,085$ $\mathrm{mg} / \mathrm{L}$. Selanjutnya nitrat yang terbentuk, oleh bakteri denitrifikasi dalam keadaan anaerob diubah menjadi gas nitrogen $\left(\mathrm{N}_{2}\right)$ yang dilepaskan dari air ke udara (Stickney, 1979)

\section{Sintasan Ikan Patin Siam}

Hasil perhitungan jumlah rata-rata ikan yang hidup pada akhir penelitian (minggu ke-8) dari masingmasing perlakuan disajikan pada Tabel 1. Terlihat bahwa sintasan paling tinggi diperoleh pada perlakuan A $(89,5 \%)$; kemudian pada perlakuan B $(81,5 \%)$; C $(78,7 \%)$; $(28,0 \%)$; dan sintasan terrendah adalah perlakuan $E$ (kontrol) sebesar $0,0 \%$. Nampaknya ada kecenderungan bahwa semakin rendah suhu perlakuan menyebabkan sintasan ikan semakin rendah.

Hasil analisis statistik terhadap data sintasan ikan patin siam menunjukkan adanya perbedaan yang nyata $(P<0,05)$ antar perlakuan. Melalui uji Duncan diketahui bahwa: antara perlakuan $A, B$, dan $C$ tidak beda nyata, tetapi ketiganya berbeda nyata dengan perlakuan $D$ dan $E$, sedangkan perlakuan $D$ berbeda nyata dengan $\mathrm{E}$.

Sintasan ikan patin pada perlakuan $A, B$, dan C yang cukup tinggi didukung oleh suhu air yang stabil dan berada dalam kisaran optimal, seperti yang dikatakan Legendre et al. (2000) bahwa suhu optimal bagi ikan patin berkisar antara $27^{\circ} \mathrm{C}-31,2^{\circ} \mathrm{C}$. Kondisi suhu yang optimal dan stabil dapat menjamin proses fisiologis khususnya derajat metabolisme sehingga mendukung kelangsungan hidup ikan.

Selain suhu, keberadaan bakteri Nitrosomonas dan Nitrobacter dalam air juga sangat menentukan sintasan ikan patin karena bakteri bioremediasi tersebut berfungsi menguraikan amonia yang bersifat toksik menjadi nitrat yang tidak berbahaya (nontoksik) sehingga tidak meracuni ikan. Sementara itu, amonia dalam konsentrasi tinggi (>0,2 $\mathrm{mg} / \mathrm{L})$ dapat menyebabkan kerusakan insang yang akan mengganggu pengambilan oksigen oleh insang, ikan menjadi hiperaktif, timbul sawan, adanya gangguan pada sistem regulasi osmotik, gangguan fisik berbagai jaringan ikan, dan dapat menyebabkan kematian.

Tingginya mortalitas ikan pada perlakuan D $(72 \%)$ dan perlakuan E $(100 \%)$ disebabkan suhu air pemeliharaan yang rendah $\left(24^{\circ} \mathrm{C}-27^{\circ} \mathrm{C}\right)$ serta mengalami fluktuasi harian. Ikan patin pada stadia benih diduga bersifat stenotermal yaitu hanya dapat mentolerir suhu dalam kisaran yang sempit sehingga perubahan suhu sebesar $2^{\circ} \mathrm{C}-3^{\circ} \mathrm{C}$ akan mengganggu proses fisiologis ikan. Perubahan suhu lingkungan dapat mempengaruhi pengambilan makanan, proses metabolisme, proses enzimatis, sintesa protein, dan difusi molekul-molekul kecil bahkan bila perubahan suhu terjadi secara mendadak akan menyebabkan kematian (Chapman, 1992)

\section{Pertumbuhan dan Konsumsi Pakan}

Secara umum dapat dikatakan bahwa bobot individu ikan patin pada semua perlakuan meningkat seiring dengan bertambahnya waktu pemeliharaan. Pertumbuhan paling tinggi diperoleh pada perlakuan $A$, disusul oleh $B$, kemudian $C, D$ dan paling rendah adalah $E$ (kontrol) yang hanya dapat bertahan sampai

Tabel 1. Rata-rata sintasan (\%) ikan patin dalam pemeliharaan dengan suhu berbeda dan inokulasi bakteri bioremediasi

Table 1. Survival rate average (\%) of pangasius reared in different temperatures and inoculated by bioremediation bacteria

\begin{tabular}{lccc}
\hline \multicolumn{1}{c}{$\begin{array}{c}\text { Perlakuan } \\
\text { Treatment }\end{array}$} & $\begin{array}{c}\text { Jumlah awal (ekor) } \\
\text { Initial }\end{array}$ & $\begin{array}{c}\text { Jumlah akhir (ekor) } \\
\text { number (fish) }\end{array}$ & $\begin{array}{c}\text { Sintasan } \\
\text { Final }\end{array}$ \\
number (fish) & Survival rate* \\
\hline A. $31^{\circ} \mathrm{C} \pm 0.4^{\circ} \mathrm{C}(+)$ bakteri (bacteria) & 250 & 223.75 & $89.5 \pm 1.97^{\mathrm{a}}$ \\
B. $29^{\circ} \mathrm{C} \pm 0.4^{\circ} \mathrm{C}(+)$ bakteri (bacteria) & 250 & 203.75 & $81.5 \pm 6.22^{a}$ \\
C. $28^{\circ} \mathrm{C} \pm 0.4^{\circ} \mathrm{C}(+)$ bakteri (bacteria) & 250 & 196.75 & $78.7 \pm 11.31^{\mathrm{a}}$ \\
D. (-) heatter (+) bakteri (bacteria) & 250 & 70 & $28.0 \pm 1.13^{\mathrm{b}}$ \\
E. Kontrol (tanpa bakteri) (without bacteria) & 250 & 0 & $0.0 \pm 0.00^{\mathrm{c}}$ \\
\hline
\end{tabular}

Angka dalam kolom yang diikuti huruf sama menunjukkan tidak beda nyata $(P>0,05)$

Value in column followed by same superscripts are not significantly different $(P>0.05)$ 
minggu ke-4. Pola pertumbuhan ikan uji cenderung berkurang dengan menurunnya suhu perlakuan.

Laju pertumbuhan individu harian (SGR) ikan uji paling tinggi diperoleh pada perlakuan suhu $A$ yaitu sebesar $6,07 \%$; kemudian perlakuan B $(5,95 \%)$; C $(5,84 \%)$; dan $\mathrm{D}(3,70 \%)$; sedangkan pada perlakuan $\mathrm{E}$ (kontrol) tidak ditemukan ikan yang hidup pada akhir penelitian. Berbeda dengan laju pertumbuhan, konversi pakan tertinggi ditunjukkan pada perlakuan $D(5,39)$; kemudian perlakuan $C(1,54)$; $B(1,44)$; dan $A(1,30)$, sedangkan perlakuan $\mathrm{E}$ tidak dilakukan pengamatan karena ikan patin tersebut sudah mengalami mortalitas pada minggu ke-5.

Hasil analisis statistik terhadap data laju pertumbuhan harian dan konversi pakan (KP), ternyata antara perlakuan $A, B$, dan $C$ tidak berbeda nyata $(P>0,05)$ tetapi ketiganya berbeda nyata dengan perlakuan D. Hal ini menunjukkan bahwa keberadaan bakteri bioremediasi sebagai stabilisator lingkungan (air) dikombinasikan dengan suhu air yang optimal $\left(28^{\circ} \mathrm{C}-31^{\circ} \mathrm{C}\right)$ secara signifikan mampu mendukung laju pertumbuhan dan konversi pakan pada ikan patin (Gambar 3).

Suhu berpengaruh terhadap aktivitas enzim. kenaikan suhu akan menyebabkan penurunan $\mathrm{pH}$ enzim dan pada $\mathrm{pH}$ rendah enzim-enzim pencernaan akan lebih mudah menghancurkan materi-materi kasar yang berasal dari makanan yang dikonsumsi. Selain itu, suhu juga berpengaruh terhadap kerja enzim pada bakteri dimana semakin tinggi suhu maka proses enzimatis atau metabolisme bakteri akan semakin meningkat sehingga aktivitas penguraian suatu bahan (amonia atau nitrit) akan semakin cepat. Kecepatan reaksi akan meningkat seiring dengan meningkatnya suhu sampai batas optimum, kemudian menurun setelah melewati batas suhu optimum tersebut. Kecepatan reaksi ini akan meningkatkan kecepatan pencernaan pakan dan digestibilitas sehingga terjadi pengosongan lambung yang mengakibatkan ikan menjadi lapar.

Pertumbuhan akan terjadi apabila terdapat kelebihan energi setelah energi yang dihasilkan dari makanan dikurangi dengan energi yang digunakan untuk seluruh aktivitas hidup termasuk energi yang hilang lewat feces dan urine. Kelebihan energi tersebut akan digunakan untuk membangun jaringan baru yang berakibat pada pertumbuhan.

Konversi pakan merupakan gambaran tingkat efisiensi ikan dalam memanfaatkan energi yang diperoleh dari makanan yang dikonsumsi. Konversi pakan yang rendah (perlakuan A, B, dan C) mengindikasikan bahwa penggunaan energi oleh ikan untuk aktivitas hidup dan yang hilang melalui jalur ekskresi (feces dan urine) relatif kecil sehingga ikan mempunyai kelebihan energi cukup besar yang dapat digunakan untuk pertumbuhan, demikian pula sebaliknya seperti yang terjadi pada perlakuan $\mathrm{D}$.

\section{Kualitas Air}

Kualitas air merupakan faktor eksternal yang sangat berpengaruh terhadap sintasan dan pertumbuhan ikan. Faktor tersebut dapat mengalami fluktuasi dan kadang-kadang ditemui kondisi ekstrim yang berubah secara harian serta musiman dan dapat mempengaruhi kehidupan ikan, baik terhadap prosesproses fisiologis maupun tingkah laku, resistensi atau kematian (Affandi \& Tang, 2002). Hasil pengukuran sifat fisika-kimia air yang dilakukan seminggu sekali

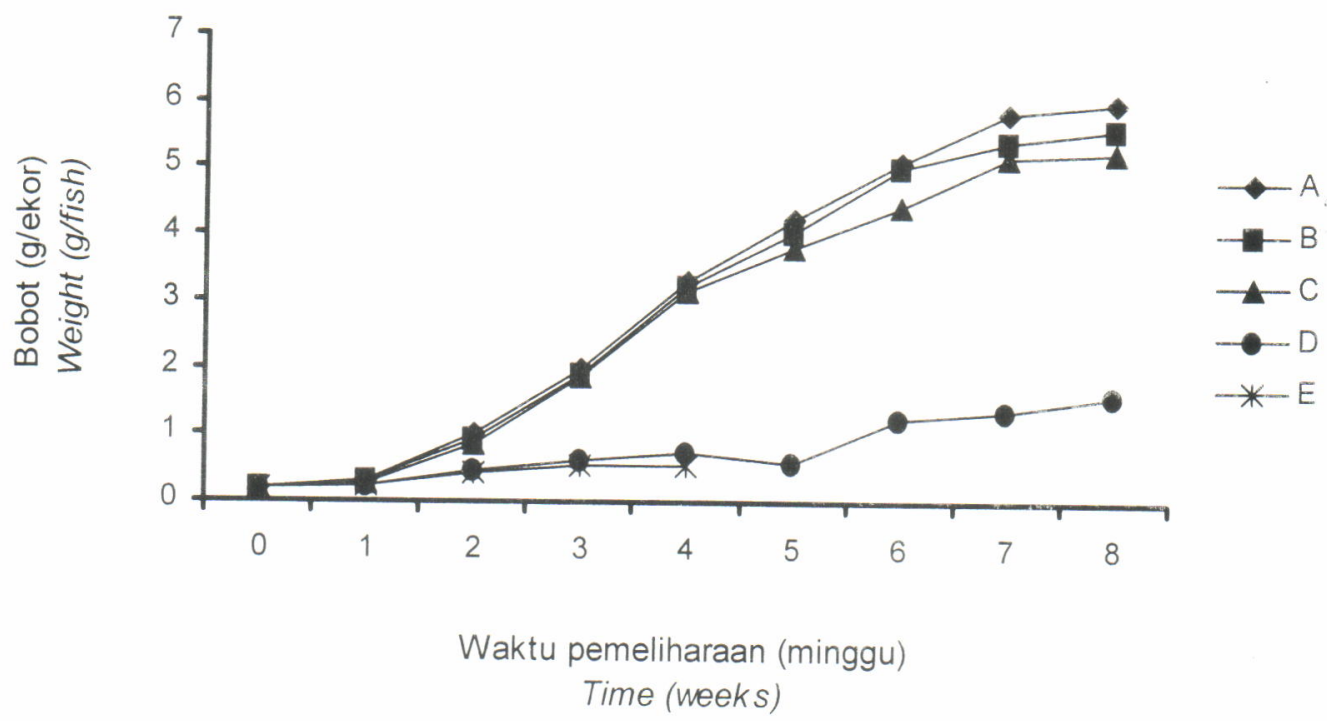

Gambar 3. Pola pertumbuhan ikan patin (g/ekor) pada suhu berbeda selama penelitian

Figure 3. Growth pattern of pangasius ( $g$ /fish) in variuos temperatures during the experiment 
selama 8 minggu pemeliharaan dari masing-masing wadah perlakuan mempunyai nilai kisaran seperti tertera pada Tabel 3.

Suhu air pada perlakuan $A, B$, dan $C$ yang relatif stabil setinggi $31^{\circ} \mathrm{C}, 29^{\circ} \mathrm{C}$, dan $28^{\circ} \mathrm{C}$ merupakan kisaran optimal untuk organisme air sehingga sangat mendukung bagi sintasan dan pertumbuhan ikan patin. Pada perlakuan $D$ dan $E$, suhu air yang rendah dan berfluktuasi $\left(24,0^{\circ} \mathrm{C}-27,0^{\circ} \mathrm{C}\right)$ kurang mendukung bahkan bersifat stressor bagi ikan, terbukti dari hasil penelitian yang diperoleh bahwa sintasan dan pertumbuhan ikan patin pada perlakuan tersebut lebih rendah (Tabel 1 dan 2). Legendre et al. (2000) berpendapat bahwa suhu air yang optimal bagi ikan patin adalah pada kisaran $27^{\circ} \mathrm{C}-31^{\circ} \mathrm{C}$ dan menurut Boyd (1991) peningkatan suhu air dapat mempercepat laju metabolisme. Percepatan laju metabolisme tersebut menurut Defrinal (2003), disebabkan meningkatnya aktivitas enzim dalam tubuh terutama dalam proses pencernaan makanan

Kandungan amonia $\left(\mathrm{N}-\mathrm{NH}_{3}\right)$, nitit $\left(\mathrm{NO}_{2}\right)$, dan nitrat $\left(\mathrm{NO}_{3}\right)$ dalam air pemeliharaan ikan patin tidak terlepas dari aktivitas bakteri bioremediasi yang diberikan. Bakteri Nitrosomonas berfungsi mengubah amonia menjadi nitrit melalui proses nitrifikasi (Stickney, 1979) dan menurut Spotte (1970), proses nitrifikasi bakteri Nitrosomonas dapat memanfaatkan amonia sebagai sumber energi untuk hidup dan pertumbuhan serta menghasilkan nitrit sebagai produk akhir. Selanjutnya bakteri Nitrobacter akan mengubah nitrit menjadi nitrat sehingga tidak berbahaya bagi ikan (Stickney, 1979). Menurut EPA(1986), konsentrasi nitrat sekitar 90 mg/ $L$ tidak akan berdampak merugikan bagi ikan.

Tabel 2. Laju pertumbuhan individu harian (SGR) dan konversi pakan (KP) pada ikan patin dengan suhu yang berbeda

Table 2. Daily individual growth rate and feed conversion of pangasius with different treatments of temperatures

\begin{tabular}{lcc}
\hline \multicolumn{1}{c}{ Perlakuan/Treatment } & SGR $^{\star}(\%)$ & KP (Feed conversion) \\
\hline A. $31^{\circ} \mathrm{C} \pm 0.4^{\circ} \mathrm{C}(+)$ bakteri (bacteria) & $6.07 \pm 0.056^{\mathrm{a}}$ & $1.30 \pm 0.014^{\mathrm{a}}$ \\
B. $29^{\circ} \mathrm{C} \pm 0.4^{\circ} \mathrm{C}(+)$ bakteri (bacteria) & $5.95 \pm 0.071^{\mathrm{a}}$ & $1.44 \pm 0.064^{\mathrm{a}}$ \\
C. $28^{\circ} \mathrm{C} \pm 0.4^{\circ} \mathrm{C}(+)$ bakteri (bacteria) & $5.84 \pm 0.078^{\mathrm{a}}$ & $1.54 \pm 0.064^{\mathrm{a}}$ \\
D. (-) heater (+) bakteri (bacteria) & $3.70 \pm 0.177^{\mathrm{b}}$ & $5.39 \pm 0.537^{\mathrm{b}}$ \\
E. Kontrol (tanpa bakteri) (without bacteria) & - & - \\
\hline
\end{tabular}

*) Angka dalam kolom yang diikuti huruf sama menunjukkan tidak beda nyata $(P>0,05)$

Value in column followed by same superscripts are not significantly different $(P>0.05)$

Tabel 3. Nilai kisaran kualitas selama penelitian

Table 3. Range value of water quality during the experiment

\begin{tabular}{|c|c|c|c|c|c|}
\hline \multirow{2}{*}{ Parameter (Parameter) } & \multicolumn{5}{|c|}{ Perlakuan (Treatment) } \\
\hline & A & B & C & D & $\mathbf{E}$ \\
\hline Suhu air (Water temperature) & $31 \pm 0.4$ & $29 \pm 0.4$ & $28 \pm 0.4$ & $24.0-27.0$ & $24.0--27.0$ \\
\hline $\mathrm{O}_{2}(\mathrm{mg} / \mathrm{L})$ & $4.05-6.62$ & $4.42--6.99$ & $4.78--8.83$ & $5.89-8.46$ & $7.36-8.83$ \\
\hline $\mathrm{CO}_{2}(\mathrm{mg} / \mathrm{L})$ & $4.90-7.99$ & $3.59--7.39$ & $4.79--7.79$ & $3.40--5.29$ & $3.00-4.79$ \\
\hline $\mathrm{pH}$ & $6.0-8.0$ & $6.5--8.0$ & $6.0--8.0$ & $7.5-8.0$ & $7.5-8.0$ \\
\hline $\mathrm{N}-\mathrm{NH}_{3}(\mathrm{mg} / \mathrm{L})$ & $0.026--0.310$ & $0.016--0.302$ & $0.023-0.345$ & $0.014--0.049$ & $0.012--0.062$ \\
\hline $\mathrm{NO}_{2}(\mathrm{mg} / \mathrm{L})$ & $0.174-4.570$ & $0.136--2.760$ & $0.115--1.270$ & $0.027--0.442$ & $0.038--0.814$ \\
\hline $\mathrm{NO}_{3}(\mathrm{mg} / \mathrm{L})$ & $0.026-1.010$ & $0.026--1.160$ & $0.026-0.736$ & $0.031--0.174$ & $0.031-0.420$ \\
\hline $\begin{array}{l}\text { Kesadahan (Total hardness) } \\
(\mathrm{mg} / \mathrm{L})\end{array}$ & $129.3--1228.5$ & $129.3--1053.0$ & $129.3--1136.8$ & $117.6--280.0$ & $125.4--249.6$ \\
\hline Alkalinitas (Alcalinity) (mg/L) & $45.76--91.34$ & $50.84--106.64$ & $50.85-91.44$ & $50.85--93.44$ & $50.85--106.98$ \\
\hline $\begin{array}{l}\text { Bahan organik (Organic matter) } \\
(\mathrm{mg} / \mathrm{L})\end{array}$ & $14.85-164.30$ & $9.11--145.36$ & $15.17--132.72$ & $6.32--42.66$ & $6.32--28.12$ \\
\hline
\end{tabular}


Kosentrasi $\mathrm{O}_{2}$ selama penelitian $>4 \mathrm{mg} / \mathrm{L}$ dan $\mathrm{CO}_{2}$ $<10 \mathrm{mg} / \mathrm{L}$ termasuk dalam kriteria yang dapat mendukung kehidupan ikan (Zonneveld et al., 1991) dan dalam kondisi seperti ini proses metabolisme ikan patin dapat berlangsung secara normal. Parameter kualitas air yang lain seperti: $\mathrm{pH}$, kesadahan, alkalinitas, dan bahan organik masih dalam kisaran layak sehingga dapat mendukung kehidupan ikan patin.

\section{KESIMPULAN}

- Kisaran suhu air antara $24^{\circ} \mathrm{C}-31^{\circ} \mathrm{C}$ tidak berpengaruh terhadap perkembangan bakteri bioremediasi (Nitrosomonas dan Nitrobacter).

- Bakteri bioremediasi yang digunakan mampu berperan sebagai remediasi biologis dan dapat mengkonversi amonia menjadi nitrit melalui bentuk intermediet yang selanjutnya digunakan untuk proses dekomposisi dan diubah menjadi nitrat sehingga tidak berbahaya bagi ikan.

- Penggunaan bakteri bioremediasi dengan suhu air berkisar antara $28^{\circ} \mathrm{C}-31^{\circ} \mathrm{C}$ dapat meningkatkan sintasan dan pertumbuhan serta menekan konversi pakan pada pemeliharaan benih ikan patin.

\section{DAFTAR PUSTAKA}

Affandi, R. dan U.M. Tang. 2002. Fisiologi hewan air. Badan Penerbit Universitas Riau. Unri Press. Pekanbaru, Riau, Indonesia, $217 \mathrm{pp}$.

Boyd, C.E. 1991. Water Quality Management and Aeration in Shrimp Farming. Puslitbang Perikanan. Jakarta, 82 pp.

Chapman, D. 1992. Water Quality Assessments. A guide to the use of biota, sediments and water in environmental monitoring. Cahpman and Hall. London, $585 \mathrm{pp}$.

Cole, G.A. 1988. Textbook of Lymnology. Third edition. Waveland Press. Inc, Illinois, USA, 401 pp
Defrinal, R. 2003. Studi Tingkat Kelangsungan Hidup Larva Keong Macan yang Dipelihara pada Suhu Berbeda. Skripsi. Manajemen Sumberdaya Perairan. Fakultas Perikanan. IPB, 62 pp.

EPA. 1986. Quality criteria for water. Jurnal EPA. Environmental Protection Agency. Woshington D.C.

Legendre, M., L. Pouyaud, , J. Slembrouck, R. Gustiano, A.H. Kristanto, J. Subagja, O. Komarudin, Sudarto, dan Maskur. 2000. Pangasius djambal: a new candidat species for fish culture in Indonesia. Indonesian Agricultural Research and Development Journal. 22(1)

Pelczar, M.J., dan E.C. Chan. 1986. Dasar-Dasar Mikrobiologi. Edisi pertama. Penerbit Universitas Indonesia, Jakarta, $443 \mathrm{pp}$.

Poernomo, A. dan A. Bittner. 1989. Budidaya Air. Yayasan obor Indonesia, $355 \mathrm{pp}$

Powell, A. 1986. Fish Desease Ang Treatments. The Hamlyn Publishing Group Ltd. Italy.

Purwakusuma, W. 2003. Kualitas air. http:/www. Ofish.com.

Salle, A.J. 1961. Fundamental Principles of Bacteriology. Fifth edition. Mc Graw hill book company, Inc. New York, $812 \mathrm{pp}$.

Steffen, W. 1989. Protein utilization by rainbow trout, Salmo gairdneri and carp, Cyprinus carpio Linn. A Brief Review Aquaculture, 23: 337--345

Stickney, R.R. 1979. Principles of Warm Water Aquaculture. John Willey and Sons. New York, 375 pp.

Spotte, S.H. 1970. Fish and Invertebrate Culture. John Willey and Sons. New York, 375 pp.

Susanto, H. 1987. Budidaya Ikan Patin. Penebar Swadaya, Jakarta, $84 \mathrm{pp}$.

Thang, N.V. 1997. Vietnam Country Report on Policies for Sustainable Shrimp Culture. Bangkok FAO Technical Consultation on Policies for Sustainable Shrimp Culture. Bangkok, Thailand, p. 133-143.

Zonneveld, N., E.A. Huisman, dan J.H. Bonn. 1991. Prinsip-Prinsip Budidaya Ikan. Gramedia Pustaka Utama. Jakarta, $318 p$ 